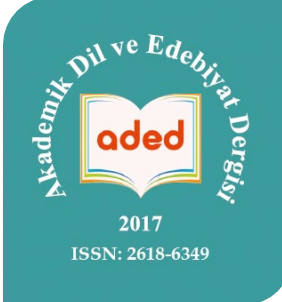

Akademik Dil ve Edebiyat Dergisi Journal of Academic Language and Literature PROF. DR. METIN AKAR'A ARMAĞAN (Cilt/Volume: 5, Sayı/Issue: 4, Aralık/December 2021)

\title{
Elif ARI
}

Doktora öğrencisi, Uşak

Üniversitesi

arielif116@gmail.com

\section{(iD}

https://orcid.org/0000-0002-1110-1873

\section{Ataç'ın Sözcükleri ve Dile Müdahale Konusu}

Ataç's Words and The Issue of Language Interference

Araştırma Makalesi/Research Article

Geliş Tarihi/Received: 12.10 .2021

Kabul Tarihi/Accepted: 26.11.2021

Yayım Tarihi/Published: 30.12.2021

\section{Atıf/Citation}

ARI, E. (2021). Ataç’ın Sözcükleri ve Dile Müdahale Konusu. Akademik Dil ve Edebiyat Dergisi, 5(4), 2303-2321. https://doi.org/10.34083/akaded.1008596

ARI, E. (2021). Ataç's Words and The Issue of Language Interference. Journal of Academic Language and Literature, 5(4), 2303-2321. https://doi.org/10.34083/akaded.1008596

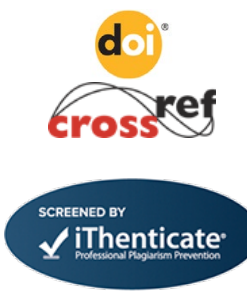

Bu makale iThenticate programılla taranmıştır.

This article was checked by iThenticate. 


\section{$\ddot{O} z$}

Tanzimat Dönemi ile başlayan dilde sadeleşme süreci Harf Devrimi ve dil reformuyla birlikte yeni bir evreye girmiştir. Bu evrede yoğun tartışmalar yaşanmıştır. Bir tarafta llımlılar; bir tarafta tasfiyeci, özleşmeci ya da öz Türkçeciler; bir tarafta ise Osmanlı Türkçesinin korunmasını savunanlar bulunmaktaydı. Bu üç grup arasında aşırıcılar olarak nitelenen öz Türkçecilerin dilde sadeleşme anlayışı özleşmedir. Türkçedeki tüm yabancı sözcüklerin atılmasını ve yerlerine dilin öz kaynaklarından sözcükler bulunup konulmasını istemişlerdir. Bu evrenin belki de en aşırıcı ismi Nurullah Ataç'tır. Çeşitli kaynaklardan bulup çıkarttığı, kendisinin türettiği pek çok yeni sözcügü yazılarında kullanmıştır. Dil devrimine, dil davasına kendini tümüyle adamıştır. Ataç, dilin özleşmesi için neredeyse herkese savaş açmıştır. Yabancı sözcük kullanan yazarları, sanatçıları yazılarında sert bir şekilde eleştirmiştir. Oldukça üretken bir yazar olan Ataç, özellikle eleştiri yazılarında oldukça öfkeli ve sert bir üslup kullanmıştır. Ataç’ın dil kavgası sadece sözcüklerle sınırlı kalmamıştır. Anlatım hususunda da müdahaleci bir yaklaşımı söz konusu olmuştur. Bu çalışmada, yazılarından hareketle Ataç'ın dile müdahaleci yönü değerlendirilmiştir.

Anahtar Kelimeler: Ataç, dil devrimi, tasfiye, dile müdahale.

\section{Abstract}

The simplification process of Turkish, which started with the Tanzimat Period, has entered a new phase with the alphabet revolution and language reform. There were moderates on one side, supporters of purification, nativisation or pure Turkish on the other, and those who defended the preservation of Ottoman Turkish on the other. Among these three groups, pure Turkish supporters, who are described as extremists, have the idea of purified in language. They demanded that all foreign words in Turkish be discarded and replaced with words from the language's own resources. Perhaps the most extremist name in this phase is Nurullah Ataç. In his writings, he used many new words that he found and derived from various sources. He is completely devoted to the language revolution, to the language cause. Ataç criticizied almost everyone for the Turkish language to be purified. He harshly criticized writers and artists who used foreign words in their writings. Ataç, who is a very productive writer, used a very angry and harsh turn of expression especially in his criticisms. Ataç's language fight was not limited to words only. He also has an interfering approach to literary style. In this study, Ataç's interfering aspect to language was evaluated based on his writings.

Keywords: Ataç, language revolution, purification, language interference. 


\section{Giriş}

Bir dilin konuşma dili ve yazı dili olarak iki cephesi vardır. Bu iki cephe arasında az ya da çok ses, şekil ve söyleyiş farklılıkları bulunmaktadır (Ergin, 2009, s. 9-11). Türkçenin tarihi seyri içinde belirli dönemlerde bu farklllıklar oldukça belirginleşmektedir. Batı Türkçesinin yazı dili tarihinin ikinci devresi olarak kabul edilen Osmanlıca/Osmanlı Türkçesi döneminde, "özellikle devlet kademesinde ve edebî eserlerde yazılanın konuşulanla bağlantısı bazen neredeyse Türkçe fiiller düzeyinde" (Kartallıŏlu, 2015, s. 8) kalmıştır. Her dilde konuşma dili ile yazı dili arasında farklar bulunur; "ancak sözünü ettiğimiz dilin, gününün konuşma diliyle ilişkisi, çok sayıda yazarın eserlerinde görüldüğü gibi, yalnızca dilin cümle yapısının büyük ölçüde korunmasından ibaret kalmıştır” (Tulum, 2011, s. 4).

Osmanlı Türkçesi yazı dili, kuruluş süreciyle beraber Arapça ve Farsçanın etkisi altına girmeye başlamış ve konuşma dilinden gitgide uzaklaşmaya başlamıştır. Arapça ve Farsçanın etkisi, dilin iç yapısından çok söz varlığını ifade eden dış yapısındadır (Tulum, 2011, s.3-4; Ergin, 2009, s.16). Osmanlıca, “Arapça ve Farsçadan alınma çok sayıda kelime, dil kalıbı ve kural ile karma görüntülü bir ‘özel dil”” (Tulum, 2011, s.4) olarak görünmektedir. Kimi araştırmacılar dilin bu özelliğini bir zenginlik olarak değerlendirmektedir: "(...) bu yazı dilinin en belirgin niteliği kelime dağarcığının zengin, dolayısıyla anlam ve kavram çeşitliliği bakımından anlatım gücünün gelişkin ve ergin olmasıdır" (Tulum, 2011, s. 3). Ancak alıntı unsurlar dili ek ve kuralları ile birlikte kaplamış, "dıştan gelen baskı, yerli dilin kendi söz varlığını ve kurallarını saf dışı ederek” dilin iç yapısını zorlamaya değin varmıştır (Korkmaz, 2003, s. 304). Arapça ve Farsçanın bu etkisi bir "istila" olarak değerlendirilmekte ve Osmanlıca "yapma" ve "karma" bir dil olarak nitelendirilmektedir: "Klâsik edebiyatın dili ise Arap ve Farsçanın etkisi altında büsbütün başka bir yol güden yapma bir dildi. Bu dil, XVI. yüzyıldan sonra konuşma dilinden büsbütün ayrıldı. O kadar ki, yalnız Türkçeyi değil, Arapça ve Farsçayı iyi bilenler bile, onu doğru okumak ve kolayca anlamakta güçlük çektiler" (Levend, 1960, s. 12), "Osmanlıca, bazılarının hâlâ sandığı ve iddia ettiği gibi, Türkçenin doğal bir gelişme sonucu meydana gelmiş doğal bir safhası değildir. Osmanlıca, imparatorluk düzeni içinde saray ve çevresinde oluşan yüksek veya hâkim sınıfın, üç dilin kelime hazinesiyle gramer kurallarından faydalanılarak meydana getirdiği melez ve yapma bir sınıf dili, daha doğrusu bir hâkim sınıf 'jargon'udur" (Tekin, 1988, s. 1029), "Bu devre Türkçenin yabancı unsurlar tarafından tam mânâsiyle istilâ edildiği, Türkçeyi Arapça ve Farsça unsurların son haddine kadar sardığı devredir" (Ergin, 2009, s. 19), "Türkçenin geliştirilmesine çalışacak yerde, işlenmiş hazır dillere başvurma gibi, aydınlardaki bilinç körlenmesinin sonucu diyebileceğimiz bu tutum, bir süre sonra dilimizi üç dilin karışmasından oluşmuş melez bir yapma dil durumuna getirmiştir” (Korkmaz, 2003, s.304). 
Osmanlı aydını, dili sanatın amacı haline getirmiştir: "Kendine özgü bir zevk ve güzellik anlayışını ön plana çıkaran bu dil sanat amacı güder. Dil bu seviyede artık 'araç' olmaktan uzaklaşmış, 'amaç' haline gelmiştir” (Tulum, 2011, s. 4). Sanatçıların bu tutumu “Türkçeyi, hor görülen, geri plâna itilen bir değer düşüklüğüne uğratmıştır. Aydınların dili ile halkın dili arasında da bir uçurum oluşmuştur” (Korkmaz, 2003, s. 304). Osmanlı aydınının halk tarafından okunup anlaşılmak gayesi yoktur. Gittikçe daha da 'ağdalı', 'süslü' bir sanat ve yazı dili anlayışı geliştirmişlerdir. Türkçe kimi zaman yalnızca yardımcı fiil ve fiilimsiler aracılı̆̆ı ile yazı dilinde yer almıştır: "bu sahada o kadar ileri gidilmiştir ki bütün isim cinsinden kelimeler ve cümle içinde isim muamelesi gören bütün kelime gurupları Arapça ve Farsça kelimelere ve terkiplere boğulmuştur. (...) umumiyetle Türkçe olarak isim ve fiil çekimi ile cümle yapısı kalmıştır” (Ergin, 2009, s. 19). Ancak, “Türkçe, Arapça ve Farsçadan mürekkep” bir dil olan bu dil genel Türkçe değildir. Halkın konuştuğu, anladığı, yeniçeri ocakları ve tekke gibi yerlerde yazılıp yazına dönüşen dile Türkçe demek daha doğru olacaktır: “(...) Türkçe ise, konuşma dili olarak halk arasında, yazı dili olarak da halk için yazılan eserlerde canlı olarak yaşıyordu” (Levend, 1960, s. 12).

Sınırlı bir çevreye mahsus olsa da sanat ve yazı dili, sanatçı ve yazarlar dilin belirleyicileridir. Fikir hareketlerinin önem kazanması ve hızlı yayılması ile birlikte bu husus daha da önem kazanmıştır: "yazı dili, yeni fikirlerin kolayca yayılmasına ve fikir hayatının genişleyip ilerlemesine en büyük engeldi. Devlet dili ise, gerek seci'ler, gerek, 'idiğünden, bulundığından', 'olmă̆ın, bulunmă̆ın', 'mebni, nâşi' gibi bağlarla birbirine eklenen zencirleme ibareler ve anlamsız deyimler yüzünden anlaşılmaz, içinden çıkılmaz bir hal almıştı. Bunun önüne geçmedikçe, Tanzimat'ın fikir cephesinin kurulmasına imkân yoktu" (Levend, 1960, s. 81). Fransız Devrimi ile halkın ve halkla gelen fikir hareketinin ortaya koyduğu gücün önemi anlaşılmıştır. Aydınlar gazetecilik faaliyetleri ile halkla doğrudan temas kurabilmiş ve yenilikçi fikirleri çok hızlı bir şekilde dolaşıma sokabilmişlerdir. Bu hızlı etkileşim gazeteleri hedeflenen kitlenin dilini kullanmaya da zorlamıştır. Bu sadeleşme hareketi sadece gazeteler ile sınırlı kalmayıp sanatın doğrudan icrası olan şiire ve oradan diğer edebi türlere de sirayet etmiştir.

19. yüzyıla girerken konuşulduğu coğrafyanın içinde bulunduğu koşullar Türkçeyi de etkilemiştir. Çoğunlukla siyasi ve ideolojik faydaya dayalı bu etki dil için olumsuz sayılabilecek bir nitelik taşımamaktadır. 19. yüzyılın ikinci yarısından sonra dil alanındaki hareketlilik yoğun tartışmaları da beraberinde getirmiştir. Dilde sadeleşme olarak anılan bu hareketlilik, Tanzimat Dönemi ile başlayıp 20. yüzyılın ilk çeyreği, oradan da özellikle Harf Devrimi ve Birinci Dil Kurultayı'nın gerçekleştiği evreler ve günümüze değin sürecek bir hareket niteliği kazanmıştır. 
Ülkenin içinde bulunduğu siyasi şartlar ve ideolojik olarak milliyetçilik akımının etkisi ile halk ve halkın kullandığı dil rağbet kazanınca aydınlar arasında uzun yıllar sürecek tartışmalar başlamıştır. Çok uçlu tartışmaların bir tarafında dilde öze dönüşü benimseyip dildeki tüm yabancı kelimelerin atılmasını isteyen "tasfiyeciler" ile yazı dili ve konuşma dili arasındaki farklılığa dikkat çekip dilde sadeleşmeye daha 1 lımlı yaklaşan diğer bir taraf bulunuyordu (Tekin, 1988, s. 1929-1930). Tartışmaların bir ucunda da dildeki Arapça ve Farsça kelimelerin dili zenginleştirdiğini savunanlar bulunmaktaydı. Öte yandan, günümüzde de çokça rastlanılan, Türkçe karşılıkları yaygin olarak kullanılan ya da Türkçesi mümkün olabilecek ifadeleri tercih etmeyip, dili Batı dillerinden kelimelerle yamayıp kullanan "özenti” bir taraftan da bahsetmek mümkündür. Ancak bu kesim dil tartışmalarının hedefinde olup tartışmalara pek dâhil olmadıkları için ayrı tutulabilir.

Tanzimat süreciyle başlayan konuşma diliyle yazma çabaları dilde sadeleşme hareketini günümüze kadar uzanan sürekli bir hareket hâline getirmiştir. 20. yüzyılın ilk çeyreğinde Ömer Seyfettin, Ali Canip, Ziya Gökalp gibi isimlerin başlattığı Yeni Lisan hareketi dilde sadeleşme konusunda yeni fikirler ortaya koyarken sadeleşme çabaları "Arapça ve Farsça" meselesi, tasfiyecilik gibi tartışmalara ek olarak Batı dillerinin, özellikle Fransızcanın, etkisi ile yeni tartışma cepheleri edinmişti. Yüzyılın ikinci çeyreğinde dilde sadeleşme çabaları resmî bir hüviyet kazanmaya başlamıştır. Önce Harf İnkılabı ve hemen sonrasında gerçekleșen dil reformları ile dilde sadeleşme çabaları kurumsal düzeyde ve ulusal olarak gerçekleşmeye başlamıştır. Mustafa Kemal Atatürk'ün 1930 tarihli yazısında "Millî his ile millî dil arasındaki bağ çok kuvvetlidir. Dilin millî ve zengin olması millî hissin inkişafında başlıca müessirdir. Türk dili, dillerin en zenginlerindendir; yeter ki bu dil şuurla işlensin... Ülkesini, yüksek istikbâlini korumasını bilen Türk milleti, dilini de yabancı diller boyunduruğundan kurtarmalıdır." (Akt. Tekin, 1988, s.1032) şeklindeki ifadeleri ulusal bir çağrı niteliğindedir.

\section{Nurullah Ataç'ın Dilciliği Hakkında}

Harf Devrimi ve dil reformları sanat ve yazı dilini doğrudan ilgilendirmektedir. Sanat dili yüzyılın ortalarına doğru konuşma diline epeyi yaklaşmıştır. Türkçenin bir yazı dili olarak kullanılabileceği görülmüş ve 'sade' bir Türkçe kullanımı araştırmacılar ve yazarlarca telkin edilmiştir. Gazete ve dergilerin sayısı artmış ve ülke çapında yaygın kullanım alanı bulmuştur.

$\mathrm{Bu}$ dönemin yazarları arasında, deneme ve tenkit yazarı olarak da nam salmış, Nurullah Ataç bulunmaktadır. Ataç'ın seveni kadar sevmeyeni de çoktur. Sevenlerince üretken ve devrimci bir yazar olarak anılmaktadır. Atatürk'ün yaptığı devrimlere sıkı sıkıya bağlıdır: "Ataç, yeni yazının kabulünden bu yana tek satır bile eski yazı 
yazmamış olan sayılı kişilerdendi. Eski yazı yazacak olursa inandığı Atatürk devrimine yan çizmiş olacağını düşünürdü” (Canpolat, 1967, s.590). Harf Devrimi ve 'Dil Devrimi'ne bağlılığını yazılarında sıkça dillendirmiştir. Bilhassa dilde özleşme konusuna çok özen göstermektedir. Onun dilde sadeleşme anlayışı özleşmedir: "Yazı devrimi yaptık. Okullarımızda artık Arapça, Farsça okutulmuyor. Bunun için dilimize girmiş arapça, farsça kelimelerin yapılarını gençler bilmiyorlar. Kelimelerin yapıları bilinmeyince de anlamları açık ve kesin olarak öğrenilemez. Çocuklarımıza Latince ve Yunanca öğretmediğimize göre Avrupa dillerinden kelime almamız da doğru değildir. O halde dilimize yerleşmiş bütün yabancı kelimeleri kovmalı, onların yerine, varsa Türkçelerini koymalı, yoksa Türkçe kök ve eklerden yeni karşılıklar bulmalıyı" (Tekin, 1958, s.408).

Ataç kelimenin kökü bilinmezse doğru anlaşılmayacağ 1 düşüncesindedir. Dili açık bir şekilde anlamak için onun kökünü tanımak bilmek gerektiğini düşünmüştür. $\mathrm{Bu}$ nedenle öz Türkçe anlayışını yıllar boyunca sürdürmüş ve bu süreçte dildeki yabancı sözcüklere pek çok karşılık bulmuştur. Özleşme hareketinin en ateşli taraftarı olarak pek çok eleştiri de almıştır.

Ataç ve onun dilciliği hakkında, özellikle ölümünden sonra, pek çok yazı yazılmış ve hâlâ da yazılmaktadır. Burada araştırmanın kapsamı ve sınırlılığı göz önünde bulundurularak fikir vermesi açısından sadece birkaçı anılacaktır.

Ataç'ın beş kitabına giren sözcükleri ele alan Talat Tekin, Ataç'ın Dilciliği ve Tilcikleri (1958) adlı makalesinde bu sözcükleri genel olarak üç kısma ayırmaktadır: ağızlardan aldığı sözcükler, Eski Türkçeden aldıkları, kendi ürettiği “tilcik”ler. Ataç’ın sözcüklere karşılık bulmada başlıca kaynakları ağızlar ve Eski Türkçedir. Ağızlardan toplanan örneklerden oluşan Tarama Dergisi ve Söz Derleme Dergisi’nden aldığı sözcükler için Tekin "Bu kelimelerin büyük bir kısmı, Ataç'ın bütün gayretlerine rağmen, yazı dilimize girememiştir." (s. 409) demekte ve bu kelimelerin neden dilde tutunamadıklarını açıklamaktadır. Alınan kelimelerin çoğunun karşılıkları zaten dilde bulunmaktadır. Üstelik Türkçede daha yaygın bir kullanıma sahip kelimelerdir. Ayrıca bu yaygın kullanıma sahip kelimelerin bazıları zaten Türkçedir. Tekin'in verdiği örnekler şöyledir: yazak (kalem), ayak (kafiye), yımızık (çirkin), küşüm (şüphe), ögseyin (elbet), sin (mezar), çimmek (yüzmek), tüm (bütün).

Ataç Eski Türkçeden aldığı kelimelerin büyük bir kısmını Divanü Lûgat-it Türk’ten, bazılarını Tanıklarıyla Tarama Sözlüğ̈̈’nden almıştır (s. 410). Tekin aynı çalışmasında, bu kelimelerin eski dilden alınırken ses ve anlam değişikliklerine dikkat edilmediğini örneklerle açıklamış ve Türkçede yaygın kullanım alanı olan kelimeler için karşılık bulmaya çalışmanın yararsız bir çaba olduğuna dikkat çekmiştir. Eski Türkçeye ancak ihtiyaç durumunda başvurulması gerektiğini vurgulamıştır. Ataç'ın 
Eski Türkçeden aldığı sözcüklere Tekin'in verdiği bazı örnekler: dek, değin (kadar), yavuz (kötü), tüp (asil), tüz (halk), taplamak (kabul etmek), ŭgum (karar).

Ataç'ın kendi türettiği kelimeleri kurulum şekline göre sıralayan Tekin, bu kelimeleri ayrıntılı bir biçimde incelemiştir: Eski Türkçeden alınan kelimelerden eklerle türetilmiş olanlar (tansıklamak "hayret etmek", bedizci "ressam", yanıtlamak "cevap vermek"...); ağılardan aldığı kelimelerle türetilenler (yöresellik "mahallilik", devinme "hareket", yeğinlemek "tercih etmek"...); Eski Türkçe ve halk ağızlarından ayırma yolu ile kurulanlar (dörüt "sanat", tükelmek "tamamlamak", usul "aklî”, betke "makale"...); başka Türk lehçelerinden aldığ kelimeler ya da bu kelimelerle kurulmuş olanlar (komuş “musiki”, ücük “harf”, şüyünçü “müjdeci”, tilcik “kelime”...); Eksi Türkçe, ağızlar ve diğer lehçelerden aldığı kelimelerle kurduğu birleşikler (bengi-su "âb-1 hayat", aktöre/sağtöre "ahlak", gökçe-yazın "edebiyat”, budunbuyrumcu "demokrat”...); yaşayan köklerden ve işlek eklerden kurulanlar (beğeni "zevk”, esenek "ilham”, öğrenek “dershane”, yapıt “eser”, öğrence "ders”, günce "gazete”, dokunca "zarar", yazın "edebiyat", sorun "mesele", eylemce "fiil”, örneğin "mesela", doğa “tabiat”...) (s.411-413).

Ataç’ın eserlerinde ve yazılarında kullandığg yeni sözcükler ile ilgili bir diğer çalışma Yılmaz Çolpan'ın Ataç’ın Sözcükleri (1968) adlı çalışmadır. Bu eser bir sözlük niteliğindedir. Bir önsöz, alfabetik düzende yabancı sözcüklere Türkçe karşılıkların listelendiği bir bölüm ve bu karşılıkların tanıklandığı asıl sözlük bölümünden oluşmaktadır. Sözlük, Ataç’ın çeşitli gazete ve dergilerde çıkan yazıları ile kitaplarının taranmasıyla oluşturulmuştur. Çolpan, Ataç'ın verdiği yabancı karşılıkları parantez içerisinde göstermiş ve sözcüklerin yazılışında Ataç’ın yazımını esas aldığını dile getirmiştir. Sözlükte kelimelerin kullanıldığı kaynaklar ve kullanıldığı cümleler verilmiştir.

Mehmet Aydın, Ataç'ın kullandığı yeni sözcüklerin tutunup tutunamadığına değinmiş ve 873 sözcükten 454'ünün Türk Dil Kurumu'nun Türkçe Sözlük'ünün son baskısında yer aldığını söylemiştir (2004, s. 345). Bu sözcüklerin neden tutunamadığına dair değerlendirmelerde bulunan Aydın, Ataç’ın dildeki aşırıcılı̆̆ına değinerek tutunan ve tutunmayan sözcüklere örnekler vermiştir.

Ataç’ın sözcükleri ile ilgili en ayrıntılı çalışmalardan biri de Sedat Balyemez’in Nurullah Ataç’ın Sözcüklerinin Kaynakları (2021) adlı çalışmasıdır. Balyemez, çalışmasında Ataç'ın sözcüklerinin kaynakları üzerinde durmuştur. Ataç'ın yazılarında kullandığ 873 yeni kelimenin hangilerinin Ataç'ın kendi türettiği kelime olduğu ve hangilerinin farklı kaynaklardan alındığı ile ilgili detaylı bilgiler verilmiştir. Balyemez, kaynaklarını şu şekilde tasnif etmiştir: “Ataç’tan önce değişik kaynaklarda aynı ve yakın anlamda tanıklanan kelimeler, Ataç’ın yapmış olabileceği kelimeler”. Çolpan’ın taradığı 873 kelimenin her biri kaynaklarda taranmış ve hangilerinin 
Ataç’tan önce kullanıldığı anlam ölçütleri de dikkate alınarak belirlenmiştir. Ayrıca daha önce yapılmış çalışmalar ile bu çalışma karşılaştırılmış ve farklılıklar belirtilmiştir.

Dil meselesinde Ataç aşırılığını “... oysaki ben dil işinde en aşırılardanım, belki de en aşırı olanım.” (1998a, s. 101) şeklinde ifade etmektedir. Bedri Rahmi Eyüboğlu'na cevaben yazdığı bir diğer yazısında "Ben 'dil işini, hayatımın en belli başlı işi olarak ele almışım.' Başka bir işim yok, yazılarımda bir şey söylemiyorum, yalnız dille uğraşıyorum, birtakım yabancı tilciklere Türkçe karşılıklar bulmaya çalışıyorum... Bunu mu demek istiyor? Hiç de öyle değilim ben. Düşüncelerimi bildirmeye çalışıyorum, bunun için de düşüncemi en açık, en anlaşılır biçimde söylemem gerektir. Dile bu yüzden önem veriyorum." (1998a, s. 269). O kendi deyişiyle belki de "en aşırı" olandır. Öyle ki dil meselesine yalnızca sözcük türeterek değil kendince 'dil yanlışlarını' da düzelterek de "en aşırı” olmayı başarmıştır.

\section{Ataç'ın Dile Müdahalesi}

Dilde sadeleşme konusunda Tanzimat ile beraber aydınlar arasında farklı görüşler belirmeye başlamıştır. Bir tarafta Türkçenin Farsça ve Arapça ile birleşimini güç sayanlar, bir tarafta dilin sade, duru bir Türkçe olması gerektiğini savunanlar ve diğer yanda 'aşırıcı' olarak nitelenen tasfiyeciler/öz Türkçeciler vardı. Bu dönemde imla, alfabe, gramer, tasfiyecilik gibi konular hakkında tartışmalar bulunmaktaydı. Dil meselesi Harf Devrimi ve dil reformuyla birlikte resmî bir nitelik kazanmış ve yoğun bir tartışma sürecine girilmiştir. ${ }^{1}$

Öz Türkçecilik yahut özleştirme tartışmasının en ateşli savunucularından biri olduğu söylenen Nurullah Ataç, dil tartışmalarına hem sözcükleri hem de 'deyiş' eleştirileri ile dâhil olmuştur.

Ataç, dildeki 'yabancı' diye nitelendirdiği sözcüklere Türkçe karşılıklar bulma ve türetme konusunda oldukça üretkendir. Bu tavrının nedenini "bügünkü koşullar içinde, tek doğru yol, usul yol bence öz-türkçedir. Okullarımızda arapça ile farsça, yunanca ile latince öğretmiyoruz, demek onların tilciklerini kullanmağa yetkimiz yoktur. Anlıyamayız, iyice, açıkça kavrıyamayız onların yorularını, köklerine inemeyiz, hangi kurallara göre yapıldıklarını bilemeyiz. Bizim için birer bilmece, kendi kendimize çözemiyeceğimiz birer bilmecedir onlar.” (1951, s.23) şeklinde ifadelerle yazılarında sıkça dile getirmektedir. Ona göre, bir sözcügün kökeni bilinmedikçe o

\footnotetext{
${ }^{1}$ Dilde sadeleşme sürecinin tarihi çok yönlü tartışmalar içermektedir. Geniş bilgi için bkz.: Levend, Agah Sırrı (1960). Türk Dilinde Gelişme ve Sadeleşme Evreleri. Türk Dil Kurumu Yayınları Ankara.
} 
sözcügün anlamı tam olarak kavranamaz. Anlam eksik olursa da düşünce açık bir şekilde ortaya konulamaz.

Onun için anlamın temeli sözcüktür: “Ataç’a göre düşünme ve anlama ile, öz Türkçecilik birbirine sıkı sıkıya bağlıdır. Köklerini, neyin nesi olduğunu bilmediğimiz sözcüklerle ne düşünebiliriz, ne de onlarla belirtilen kavramları anlayabiliriz. Bu nedenle öz Türkçeye yönelmeliyiz" (Özdemir, 1968, s. 156). Sözcüğün taşıdı̆̆ı anlamın eksiksiz kavranması düşünceyi ve anlatımı da tam kılmaktadır.

Aslında Ataç'ın karşı olduğu yabancı unsurlar Arapça ve Farsça sözcük ve dil kurallarıdır: "O, Arapça ve Farsça bilmeden, bu dillerin kök ve ekleriyle üretilen kelimeleri kullanmanın bir sistemsizlik olduğunu, sistemsizliğin ise düşünceye, insan kafasına değer veren bir toplum için affedilmez bir kusur olduğunu savunurdu" (Ağakay, 1957, s.558). Bu tutumunun dayanağını ise "Dedelerimizde dil duygusu varmış. Konuşma dilinden, kamunun dilinden ayrı bir bilim dili, bir dörüt (sanat) dili kurmuşlar, ona aldıkları tilciklerin anlamlarını, köklerini, ne türlü kullanılması gerektiğini bilerek almışlar, sonra o tilcikleri konuşma diline, kamu diline işletmeyi de başarmışlar.” (1998a, s. 349) şeklinde açıklamaktadır. Bu ifadelerinin ardından çağdaşı olan yazar ve aydınları dil duygusu olmamakla, kullandıkları sözcükleri düşünmemekle suçlamaktadır.

Eskilerin Arapça ve Farsçayı bilerek ve anlayarak kullanmalarını, bu kullanımın dil bakımından doğruluğunu dile getiren Ataç, Osmanlıcaya değil Arapça ve Farsçanın bilinmeden, anlaşılmadan kullanılmasına karşı çıkmaktadır: "okur yazarlarımızın bu iki dilin kurallarına yabancı olmadıkları sürece Osmanlıca pekâlâ bir dildi; çünkü bir sisteme, bilinen, kavranılan bir sisteme dayanıyordu; fakat bu diller öğretimimizde yer almamaya başladıktan sonra Osmanlıcayı yaşatmak istemek doğaya aykırı bir davranış, kafa eğitimine zararlı bir zorlayış olurdu. Bu sonuca vardıktan sonra dilimizin ayrıldığı eski sistem yerine Türkçeye, Türk dilinin kaynak ve kurallarına dayanan bir yenisini almaktan ve bunu eksiksiz uygulamaktan başka yol kalmıyordu." (Ăgakay, 1957, s. 558).

Ataç yine bir eleştirisinde: "Her işte olduğu gibi dil işinde de başlıca yağımız (düşmanımız) bu Doğulu düşünüşü, Doğulu görüşüdür. Ondan silkinmedikçe ne dilimizi düzeltebiliriz, ne de gerçekten uygarlık yolunda girebiliriz” (1998a, s. 242). Ona göre, Latince ve Yunanca eğitimin bir parçası olmalıdır ki Batının uygarlığına ulaşabilelim.

Ataç, 'bilim-sözleri' ile ilgili giriştiği bir eleştiride 'oksijen' sözcüğünün yazımını değerlendirirken şu sözleri söyler: "Hayır, sayın bayanlar, sayın baylar, o gösterdiğiniz bilim-sözleri, uluslararası sözler değildir. Alamanlar, Fıransızlar, İngilizler, İtalyanlar hep onları kullanıyorlarmış; daha da var: İspanyollar, İsveçliler, Norveçliler, Ruslar, 
Felemenkliler... Ne gösterir bu? O saydı̆̆ınız uluslar, birbirinden büsbütün başka, büsbütün ayrı topluluklar mıdır? Aralarında bir birlik yok mudur? Onlar, okullarında yüzyıllardan beri yunanca, latince öğreten, Yunan-Latin ekini ile beslenmiş, dillerini yunanca ile latince üzerine kurmuş uluslardır, aralarında bir ekin birliği, bir tarih birliği vardır. Bir İngiliz için, bir Fıransız, bir Alaman, bir Rus için yunanca, latince bir söz, büsbütün yabancı bir söz değildir; Yunanlardan, Latinlerden kanca ayrı olsalar dahi (değildirler, hepsi bir köktendir onların), ayrı olsalar dahi Yunanların, Latinlerin edebiyatını çocuklarına okuturlar, latince ile Yunancayı bilim dillerinin anaları diye almışlardır. Biz öyle miyiz? Biz okullarımızda çocuklarımıza yunanca, latince öğretiyor muyuz? Uluslar-arası bir dilmiş o dil... Değil, Efendim, Yunan-Latin ekininden geçmiş bir camianın dili. Biz de katılalım onlara. Peki, yunanca ile Latinceyi öğrenerek katılalım, biz de gerçekten girelim o camiaya, onlara uzaktan benzemeğe kalkmıyalım" (1962, s. 717).

Ataç'ın özleşme çabası ve ısrarı Türkçeleşmeden ziyade, Yunanca ve Latincenin öğretilmemesi sonucu zorunlu bir yönelim gibidir. Bu durum öz Türkçecilik ve onun dayandığı fikirlerle çelişmektedir. Öz Türkçeciler dildeki yabancı unsurların tamamına karşı dururlar. Arapça-Farsça, Latince-Yunanca ayrımı yapmaksızın dil meselesine özcü bir biçimde yaklaşırlar. Ataç’ın özleşme çabası ise farklıdır. Batıcılığa dayanan bir çabadır. Ataç’ın okullarda Latince-Yunanca öğretilmesi isteği gerçekleşmekten uzak olduğu için dilin kendi kaynaklarından sözcük bulup türetilmesi yolunu seçmiştir: “(...) Humanist Ataç’a göre medenî bir dil Lâtince ve Yunanca köklerden yaş almadıkça yeşeremeyeceği, bu da bizim için güç olduğu için kökü kendi dilimizden alma inancına vardı" (Yücel, 1957, s. 562).

Ataç'ın bu tutumu bazı çevrelerce farklı algılanmış ve bazılarınca da yanlış anlaşılmıştır. Doğrusu, bu ikilik yanlış anlaşılmalar ve çelişkiler doğurabilen bir nitelik taşımaktadır. Bazı kesimlerce "dil ırkçılığı” yapmakla suçlanmış ve "dinsiz" olmakla yaftalanmıştır. Burada yapılacak olan yorum ve değerlendirmeler, yanlış anlaşılmaya mahal vermemek adına, bu türlü görüşlerden uzak, tümüyle dil meselesi gözetilerek yapılmıştır.

Bir diğer çelişki ise sözcüklerin kökenleri konusundadır. Ataç, "Yabancı bir sözü savunmak, yerine Türkçesinin geçmesine engel olmak istediler mi, çoğunluğu, kamuyu ileri sürüveriyorlar: 'Bu sözü bilmeyen mi var bu ülkede? Yaşlısı, genci, köylüsü, kentlisi, hepsi biliyor, başkasından duyunca anlıyor, kendileri de kullanıyorlar. Neden atacakmışız onu?' diyorlar. Ziya Gökalp da: 'Türkçeleşmiş türkçedir' demiş, vermiş özleştirmecilerin payını.” (1959, s. 444) ifadelerinin ardından 'istiklal' sözcügünü örnek gösterir. Bu sözcügün kökü olan 'kılle’nin çoğunluğun bilemeyeceğini, bu sözcügün Türkçede yaratılıp Arapçaya geçtiğini, 'bağımsız' karşılı̆̆ının kullanılmasının bu nedenle daha uygun olduğunu söylemektedir. Ataç bu 
tutumunu kendince bilimsel bir zemine oturtmaya çalışsa da, Eski Türkçeden devşirdiği sözcüklerin kökü, ilgili çevreler harici, halka 'istiklal' sözünün kökünden daha az yabancı değildir.

Ataç'1n bu tutumunu Batu "Kitap değil betik diyor meselâ. Niçin kitap değil? Niçin betik?... Çünkü kitap Türkçe değil... Çünkü bu kelime Arapça... Betik de Türkçe bir kökten imiş... Acaba hangi kökten? Ben düşünmekle çıkaramıyorum bunu. Belki ölmüş bir köktür, Ataç en eski Türkçe kökleri de diriltmeğe çalışıyor. Ama akademik planda belki doğru olabilen bu anlayış yaşayan bir dil söz konusu olunca doğru mudur? Bana bugün hiçbir şey söylemeyen eski Türkçe kelimeler ya da kökler, bir yazar onları kullanınca dirilebilirler mi?” (1965, s. 312) ifadeleriyle eleştirmektedir.

Ataç, dil konusunda uzman ya da bilgin değildir. Bu durum bulduğu ve türettiği sözcüklerin kendi fikirleriyle çelişmesine neden olmaktadır: "çirkin kelimesinin, elbet'in, şüphe'nin yapılarını gençlerimize öğretebiliriz, çünkü biliyoruz. Fakat yımızık’ın, öğseyin'in, ve küşüm'ünkini öğretemeyiz; çünkü Türk dili üzerindeki çalışmalar henüz bu gibi kelimelerin yapısını çözebilecek durumda olmaktan çok uzaktır” (Tekin, 1958, s. 409). Ataç, sözcük köklerini bilmeyi bilimsel bir temele değil varsayımlara dayandırır: "Konya'da öyle derlermiş de onun için. Sonra küşüm tilciğinin başka yerlerde başka anlamlarda kullanıldığını öğrendim. Kökünü bilmiyorum. Konya'da şüküm dedikleri de olurmuş. Arapça şek'in bozması olacak. Bunun için şimdi sizin diyorum. Onu da pek beğenmediğim için daha bir iyisini arıyorum” (Akt. Çolpan, 1963, s. X-XI). Bu ve bunun gibi varsayımlar şekilci ve sezgiseldir.

Burada değinilmesi gereken bir diğer nokta da Ataç’ın bulduğu ve türettiği kelimeler konusundaki kararsızlığgdır: "Şimdiye dek kelime yerine keleci diyordum, pek de beğenmiyordum; çünkü keleci, kelime değil; söz demektir. Bundan böyle tilcik, belki de tilce diyeceğim. Til, dil lügat demektir, tilcik, tilce de 'küçük til' demek olur." (Akt. Çolpan, 1963, s. V). Keyfî bir tutumla, bulduğu kelimeleri beğenmediği takdirde bir yenisi ile değiştirmekte bir beis görmemiştir: "Bulduğu bütün kelimelerin tutunacağını sanmazdı. Hattâ az sonra kendi de beğenmeyip değiştirdikleri olurdu. Fakat bu işin ancak böyle, yaza boza yürüyeceğine inanmıştı” (Ağakay, 1957, s. 558).

Sözcük konusundaki aşırıcılığı Ataç'ı zaman zaman zaten Türkçesi bulunan sözcüklere Türkçe karşılık bulmaya değin vardırmıştır. 'Çimmek' ve 'tüm' kelimelerinin yazı diline önerilmesine karşılık Tekin: “çimmek ve tüm de boş yere yazı diline sokulmak istenmiştir. Çünkü bunların yazı dilimizdeki karşılıkları olan yüzmek ve bütün kelimeleri zaten Türkçedir” (1958, s. 409) yorumlarında bulunmaktadır.

Ataç'ın dil ve dil eleştirisi üzerine pek çok yazısı bulunmaktadır. Özcülügünün merkezinde sözcükler vardır. Ataç, dilde yaygın kullanımı bulunan yabancı 
sözcüklerin kullanımına bile oldukça öfkeli ve sert bir tavır takınır. Eleştiri yazıları ile yabancı sözcük kullanan herkese savaş açmıştır. Kendisine kitabını gönderen Dr. Semih Sümerman’a “İyi ya! Bana bildirmesin düşündüklerini Bay Dr. Semih Sumerman, anlamam da onun için. Bakın ne yazmış bana gönderdiği kitabın üzerine: 'Muhterem fikir üstadımız ve değerli münekkit Nurullah Ataç bey ef. ye gıyabî saygı ve sevgilerimle.' 1955 yılında, bu giyabî tilciğini görürüm de sinirlenmez miyim? Bunu hiç düşünmemiş mi?", "Siz, bütün o yabancı tilcikleri doldurduğunuz kitabı, benimle alay etmek için mi gönderiyorsunuz bana?", "Size şunu da söyleyeyim: Ben bağnazım (mutaassıbım). Dil alanında bağnazım. 1955 yılında, o sizin kullandığınız tilciklerle gerçekten düşünülebileceğine inanmam" (1998a, s. 349-350) yolunda eleştiriler yapmış ve onu düşünmemekle suçlamıştır.

Ataç'ın bu tür eleştirilerinden dönemin yazar ve sanatçılarının çoğu payını almıştır. Hatta öz Türkçeci olan ılımlı çevre bile eleştirilerinden payını almıştır. Atalay Yörükoğlu için "Dil devriminden yanaymış kendisi, Türkçeden yabancı tilciklerin arınmasını istermiş, gene de ılımlı olmayı öğütlüyor, aşırı gidersek yoksullaştıırmışı Türkçeyi...", "Bay Atalay Yörükoğlu gibi bize dudak bükenler ise o yabancı tilcikleri, anlamlarını iyice kavramadan, gelişigüzel almamızı istiyorlar.” (1998a, s. 326-327) gibi eleştirilerde bulunmuştur.

Ataç, yabancı sözcük kullanan hemen hemen herkesi düşünmemekle, anlamamakla itham eder ve öfkeli bir üslupla sert bir şekilde eleştirir. 1951 yllından ölümüne değin Türk Dil Kurumu'nda Yayın Kolu Başkanı olduğunu ve Türk Dili dergisini yönettiğini bilmekteyiz (Aydın, 2002, s. 841). Buradaki görevi dolayısıyla dil hakkındaki görüş ve düşünceleri önem taşımaktadır. Onun öfkeli ve sert tutumu, dil çevresini rahatsız etmiştir.

Aşırıcılık konusunda öyle ileri gitmiştir ki bazı yazıları, özellikle son dönem yazıları, yabancı sözcüklerden arınmış "yabancı" bir Türkçeyle yazılmıștır: "Böyle saçma bir tartışmada tüzecilerin savını beğenenler için bir kıyın (ceza) biçmeli: Sayrı (hasta) düştüler mi, bir sağın bile gitmemeli onlara bakmaya. Tüze kurtarsın onları acı çekmekten, ölümden...” (1998b, s. 181), "Görmük ise çok para isteyen bir dörüttür, o parayı birden çıkarmak ister. Bunun içindir ki görmük tellim (daima) günün beğenisine uymak gücemindedir (mecburiyetindedir)." (1998b, s. 226-227), "Çok kimseler, dörütün, gökçe-yazının ödevi, kızlarını varlıklı kocalara sağlam ulaştırmaktır sanıyorlar. Sağ-töre dedikleri de bu... Yazar, öldürücüleri birer yiğit diye övebilir, uğruları (hırsızları), da övebilir, kovuşturmaya uğramaz. Biraz açık bir söz söyledi mi! toplatılır betiği" (1998b, s. 262)...

Ataç'ın Tarama Dergisi, Söz Derleme Dergisi gibi ağızlardan derlenen yayınlardan çıkarıp kullandığı sözcüklerin tutulmaması yazı dillerindeki karşılıklarının daha yaygın kullanımlarının olması ile açıklanabilir (Tekin, 1958, s. 
409). Diğer bir sorun da alınan sözcüklerin yazılış ve söylenişleri ile alakalıdır: "Bilindiği gibi ağızlar kelimelerin doğru söylenişlerini, çok kere, bozar. Meselâ küçük kelimesi birçok Anadolu ağılarında güç̧̧ük şeklindedir. Bu şüphesiz ki bozuk ve kelimenin yapılışını çözmeğe yaramayacak bir söyleniştir” (Tekin, 1958, s.409). Burada "kelimenin doğru söylenişi” meselesi ayrı bir tartışma konusudur. Alınan sözcügün yazılışı ve söylenişindeki farklılıklar tutarsızlığa, ikiliğe neden olacağı muhakkaktır.

Eski Türkçeden aldığı sözcükler için de benzer bir durumdan bahsedilebilir. Dilin fonetik ve semantik gelişimine dikkat edilmeden alınan sözcükler dilde bir tutarsızlık meydana getirecektir. Ataç’ın "tilcik” sözcüğü dilin fonetik gelişimine aykırı bir tutumla türetilmiştir.

Ataç dili bilmenin önemini sıkça dile getirmekte ve eleştirilerini dili bilmeme, düşünmeme üzerine yapmaktadır. Ancak kendi sözcüklerinin kuruluşundaki fonetik, morfolojik ve semantik yanlışlara (Tekin, 1958) bakıldığında, Ataç'ın bir dil uzmanı olmadığını da hatırlayarak, kendi söylemlerindeki zayıflıkları görülmek mümkündür.

$\mathrm{Ne}$ şekilde olursa olsun, sözcüklerin bir dilde tutunup tutunmaması konuşucularının inisiyatifindedir: "Sözlük sayfalarında unutulup kalmış olan eski bir kelime, bazı kere toplum içinde beliren yeni bir kavramı belirtmek üzere, bir fikir adamının kalemiyle yeniden ortaya atıldığı gibi, bazı kere de yenilik göstermek hevesine kapılan bir sanatçının eserinde yer bulabilir. Çok kere sözlüklerde ve dil haznesinde bulunmıyan bir kelime, üretme yolu ile eski bir kökten de çıarılabilir. Bunların hepsi, halkdan iyi kabul görürse yerleşir ve dile malolur" (Levend, 1960, s.87).

Ataç, dili sadeleştirme çabasını sadece sözcük düzeyinde tutmamıştır. 'Dil yanlışları'nı düzeltme işine de girişmiştir. Aydın, Ataç’ın eleştirdiği dil yanlışlarını "Gereksiz kullanılan ögeler, eş anlamlı ögeler, birbirine karıştırılan sözler, çeviri ögeler” (2002) şeklinde alt başlıklar halinde değerlendirir: "Nurullah Ataç, en çok gereksiz kullanılan ögeler üzerinde durmuş, en kestirme anlatımları göstermiştir. Güzel yazmak, az sözle çok şey anlatmak biçiminde de anlaşılabilir. Yaşadığı dönemde yaptığı yanlış avcılığı dolayısıyla Ataç birçok yazarın korkulu rüyası olmuştur" (Aydın, 2002, s.842).

Deyiş meselesinde bu tavrını Özdemir, "Ataç için Öz Türkçeci olma, eski sözcüklerin yerine yenilerini, öz Türkçelerini geçirme değildir yalnızca. Önemli olan düşüncenin biçimlendirilişinde, anlamın örgülendirilişinde de kalıplaşmadan sıyrılmadır. Tümceyi her türlü ayrıntıdan soymadır. Düşüncenin soluğunu sözcük boğuntusuyla kısmamadır. Anlatıyı 'kitâbet dili’nin asık suratlılığından kurtarma, konuşma dilinin kıvraklığına yaslandırmadır. Halkın 'kara cümle' diye nitelendirdiği bezeksiz, donaksız anlatım biriminin inceliklerini arayıp bulmadır.” (1977, s. 413) şeklinde açıklamaktadır. 
Ataç’ın gereksiz sözcük kullanımı sadece yabancı sözcükleri kullanma ile sınırlı değildir. Bir spor haberini eleştirdiği yazısında "Bügünkü Son Havadis'in son üzünde kocaman bir başlık gözüme ilişti: 'F. Bahçe, Beşiktaş ve G. Saray’ı dize getiren Beykoz...' 'Dize getiren...' Ne oluyoruz? Yenen demek yetmiyor mu? Bu takımlar birbirinin kanına mı susamış?” (1998b, s. 255) yorumunu yapmaktadır. Ona göre deyiş, anlatım en "bezeksiz" şekilde ifade edilmelidir.

O, sadece düz yazıları değil şiirleri de eleştirir. Söz gelimi Yahya Kemal'in "Bă̆rımda varı Byron'u bedbaht eden melâl / Gezdim o yaşta kırları, hülyam içinde lâl" beyiti için "Bunda belli oluyor ozanın uyak aradığı, 'çatlatıyor' uyağı. 'Lâl, burada yersiz, gereksiz!” diyoruz, bütün tat bozuluyor...” (1998b, s. 125) ifadelerini kullanır.

Ataç, deyişi şu şekilde açıklamaktadır: "Bir yazar için en başta gelen şey deyiştir, elbette, üsluptur. Düşünce olduğunu sananlar yanılırlar. $\mathrm{Ne}$ ile anlatırız düşüncelerimizi? Karıncalar küçük oynak boynuzlarını birbirlerininkine dayar da öyle bildirirlermiş birbirlerine ne istediklerini, bizim var mı öyle boynuzlarımız? Bizim dilimiz var, deyişimiz var, onunla bildireceğiz.” (1998a, s. 46). Onun deyiş anlayışı gereksiz sözcük kullanımından, eş anlamlılardan kaçınmaktan ileri gelir. Dili az ve öz bir biçimde düşünce aktarımı için kullanmak gerektiğine inanır. Dilin zenginliğinin 'parlak lakırdılar' ile ölçülmediğini vurgular.

Sözcükler konusunda olduğu gibi anlatım ve deyiş konusunda da aşırıcıdır. Dostu olarak gördüğü Tanpınar’ı bile eleştirmiştir. Kısakürek ile giriştiği polemikler ise malumdur. Döneminin edebiyat otoritelerinin sert eleştirilerine maruz kalmıştır. Hatta bazı kesimler tarafından aşağılanmaya varan eleştiriler dahi almıştır.

Ataç, maruz kaldığı bu eleştiriler karşısında zaman zaman ümitsizliğe kapılmıştır (Çolpan, 1963, s. VIII-IX). Ancak dil kavgasını asla bırakmamış, ölene dek sürdürmüştür. İnandiğı amaçlar uğruna pek çok şeyi feda ettiği söylenmektedir: “Ataç, Osmanlıca yazılariyle edebiyat tarihine geçecek bir ad kazanmıştı. Dil devriminin öncüleri arasında da yoktu. Ama az sonra anladı ki dilimizde tutulması gereken yol budur. O zaman edebiyat tarihinde kendisine yer kazandıran Osmanlıca üslûbunu hiç acımadan çiğnedi ve işe sıfırdan başladı. Fedâkarlığı büyüktü” (Aksoy, 1958, s. 423). O, kendi inancını dili arındırmak olarak fikrileştirmiştir: “... Ataç, temizlenme akımının öncüleri arasında yoktu. Bir zaman sonra bunun gerekliliğine o kadar inandı ki öncülerin ölçüsü, kendisinin ölçüsü yanında çok güdük kaldı. Ataç, en geniş anlamiyle arıtıcı idi. Son yıllarında, içinde tek yabancı söz bulunmıyan yazılar yaziyordu" (Aksoy, 1960, s.418).

Ataç, öfkeli ve oldukça üretken bir yazardır. Kendisini dahi eleştirmiştir: “Bügüünkü Dünya'da çıkan 'Etki' adlı yazımı okudum. Gereksiz çok nenler söylemişim, öze de pek dokunmamışım. İvecenlik edip çabuk yazıyorum. Bu son aylarda boyuna 
yazıyorum. Kiminin çenesi düşer, benim de yazağım (kalemim) düştü.” (1998b, s.98), "Ulus'ta Perşembe günü çıkan 'Özgür Yazar' adlı yazımı okuyayım dedim, yarısına güç ulaştım. Ben ne yazdım, dizmen ne dizmiş!.. Şöyle bir yer var: 'Bay Fethi Naci okumuş o yazıyı, beğenmemiş dediklerimi ne zaman payımı vermek için yazarına sartlamış...' Ne demek bu? Ben böyle bir nen yazmadım. Ben şöyle yazmıştım: 'Bay Fethi Naci okumuş o yazıyı, beğenmemiş, ağzımın payını vermek için yazağına sarılmış..."”(1998b, s. 109).

Onun "otuz yıllık yazılarında ve konuşmalarında incelenirse zaman zaman, bağlandığı düşüncelerin birbirini çeldiği görülür. Kendisi de bunu itiraftan, hattâ kabulden çekinmezdi. Değiştiğini, fikirlerinin de bu değişmeye göre olduğunu söylerdi. Fakat muhakkak olan şurasıdır $\mathrm{kr}(\mathrm{ki})$, hangi sürede neyi ileri sürmüşse inandığı odur." (Yücel, 1957, s. 562). Bu çelişkilerin bir kısmına yukarıda değinilmiştir.

Ataç, kendini dil otoritesi addedip dil çevresindeki herkese müdahale hakkını kendine tanımıştır. Tanıdığı olsun ya da olmasın, söz konusu dil olduğunda sert bir üslup kullanmaktan kaçınmamıştır. Bunu bir dava olarak görmüş, eleştirilerinde ölçü tanımamıştır. Yazılarında kendisine yönelik eleştirilere cevaplarında ise alıngan bir tavır takınmaktadır. Dil konusunda kendi 'yetersizliğinden' ve 'güçsüzlügünden' bahsetse de (1998a, s. 134) herkese güçsüz ve yetersiz olarak yaklaşan da kendisidir. Ataç, kendini adeta bir 'dili doğru kullanma kılavuzu' gibi görmektedir. Öyle bir kılavuz ki herkese içinde bulunduğu dil yanlışlarını göstermekte ve doğru olanın ne olması gerektiğini bildirmektedir.

Dil davasını dil devrimi ile ilişkilendirmekten geri durmamış ve dil devrimini sahiplenmiştir. Saim Ali Dilemre'nin ölümü üzerine yazdığı bir yazıda “...bizler, dil devrimine çalışanlar, doğru yoldayız, gün geçtikçe sayımız artıyor, artık hiçbir şey bizi zayıflatamaz" (1998a, s.168) ifadeleri ile bu sahiplenmeyi vurgulamıştır.

Dil reformu Türk yazı dilini konuşma diline yaklaştırmayı planlayan bilinçli bir dil hareketidir. Dile yazı dili üzerinden müdahale yapılmıştır. Konuşma dilinde yaşayan sözcükler, ağır ve anlaşılmaktan uzak tamlama ve ifadelerin yerine kullanılacak, yazı dili böylece sadeleşecek ve halkın da anlayabileceği bir dil olacaktır: "Türk Dili Reformu dile yapılan bilinçli bir müdahaledir. Bu müdahalenin amacı bir Türk yazı dili kurmak, Türkçeyi bilim dili yapmaktır. Türk yazı dilinin halkın konuştuğu dilden uzaklaştığ 1 daha önce de dile getirilen ve bilinen bir gerçektir. Reformun amacı yazı dilini halkın konuştuğu dile yaklaştırmaktır” (Aydın, 2004, s. 346).

Bu müdahalenin en büyük çıkmazı "Hangi Türkçe?” sorunudur. Daha özelde "Halkın konuştuğu hangi Türkçe?” sorunuyla devam eder. Bu soruna bir çözüm önerisi Şemsettin Sami’den gelmiştir: “İstanbul Türkçesinin sslâhiyle meydana gelecek 
edebî dilin, zamanla bütün Türkler’in kabul edeceği genel bir dil haline gelmesini istemektedir" (Levend, 1960, s.223). Bu sorun yazı dilinin belirleyicisi durumundaki aydın çevrenin yoğun olarak bulundukları yerin İstanbul olması ile nihayetinde uzlaşılan dilin İstanbul Türkçesi olmasıyla çözüme kavuşmuştur. Yayın ve gazetecilik faaliyetlerinin de aynı çevrede yürütülmesi ile doğal bir uzlaşıma varılmıştır.

Dile yapılan her müdahale dilin doğal gelişimini etkilemektedir. Hüseyin Cahit Yalçın, Birinci Dil Kurultayı'nda yaptığı konuşmada "Yirmi yirmi beş sene evvel kullandığımız birçok Arapça ve Acemce kelimelere bugün hiç ihtiyaç hissetmiyoruz. O kelimeler dilden ne bir akademi kararı ile çıkarıldılar, ne ceza kanununun mahsus bir maddesiyle... Lisanın tabiî seyri bu neticeyi temin etti. Lisanın tabiî seyri biribirine girişik pekçok âmillerin neticesidir. Bu âmiller arasında fikrimize uygun gelmiyenler olabilir. Fakat unutmayalım ki bunlar da, hürmete şayandırlar. Çünkü iyinin ve doğrunun mehenk taşı bizim kendi fikrimiz ve hissimiz değildir. İçtimaî bir müessese olana dil, tam demokrat bir vasf ile, ekseriyetin zımnî kabul ve kararı dairesinde yoluna devam eder." (Maarif Vekaleti, 1933, s. 275) sözleri ile dilin doğal gelişiminin önemini vurgulamaktadir.

Üzerinde durulması gereken önemli noktalardan birisi de Türkçenin sürekli olarak başka dillerin hegemonyasında olması gerçeğidir. Ataç, özleşme davasında özü savunduğu halde ideolojik olarak Batıcılık fikrindedir ve Batı medeniyetlerine ulaşmanın Latince ve Yunanca bilmekle olabileceğini savunmaktadır. Ancak dil bilmek ile dili başka bir dilin hegemonyasına almak farklı şeylerdir: "Ne vakte kadar ötekinin berikinin edebiyyatını taklid edüp duracağı? Acem mukallitliğinden kurtulur kurtulmaz Arabistan çöllerinde kefaret mi çıkaracağız? Edebiyyatımız artık Türk olsun, buna çalışalım. Nasihat vereceksek hep bu yolda verelim. Arab'ın dekayık1 şeriyye ve hayalât-1 metinesi kendisine mübarek olsun. Biz bunları niçün alalım? Bizim kendimizin hayalimiz, karihamız yok mu?” (Levend, 1960, s.208).

\section{Sonuç}

Dili sadeleştirme davasında konuşma dilini esas alıp gitgide halkın bile anlayamayacağı bir dil inşa eden Ataç'ın dile bu denli müdahalesi yaşayan dilin doğasına aykırı bir tutumdur. Ortaya koyduğu fikirlerin bilimsel dayanağı yine kendi fikirleridir. Dili sevmekten, dile bağlılıktan gelen bir romantizmle kendini dile adamış ve öznel, sert bir tavırla dil davasını yürütmüştür. Sonuçta ortaya çıkan dil en başta anlaşılmadığı için eleştirilen dilden pek de farklı olmamıştır. Ataç’ın özleşme davasının dilde sadeleşme sürecine katkıları herkesçe malumdur. Onun sözcükleri ya da dil davası ile ilgili sorun tutumudur. O sadece çağdaşlarıyla değil dil ile de kavgalıdır. Yaygın kullanılan yabancı sözcüklere dahi karşıdır. Onun davası dili sadeleştirmekten ziyade dili özleştirmektir. Ona göre, bir dil bilinmiyorsa onun sözcükleri dilde yaşasa 
dahi kökü, bağı bilinmediği için anlaşılamaz. Arapça ve Farsçanın bilindiği, okullarda okutulduğu dönemlerde bu dilin sözcüklerini kullanmakta sakınca yoktur. Ancak onun döneminde Arapça ve Farsça okullarda öğretilmiyor ve bu yüzden bilinmiyordu. O halde bu iki dilin sözcükleri de kullanılmamalıdır. Çünkü düşünüşün ve anlamın açık ifadesi ancak sözcüklerin ait olduğu dili bilmekle mümkündür. Diğer taraftan Ataç, uygarlaşma düşüncesi ile okullarda Latince ve Yunanca öğretilmesini ve dilin bu iki dilin ekiniyle yeşermesini istemiştir. Bu dileğinin gerçekleşmeyeceğini anladığ vakit, tek çarenin dilin öz kaynaklarında olduğunu düşünerek dili istisna kabul etmeyecek biçimde özleştirmek gerekliliğine inanmıştır. $\mathrm{Bu}$ inancı onu türlü kaynaklardan sözcük almaya ve türetmeye yöneltmiştir. Ataç, dil özleşmesini sözcüklerle sınırlandırmamış, anlatımın da özleşmesi gerektiğini düşünmüştür. Gereksiz sözcük kullanımından, eş anlamlı kullanımlardan dilin arındırılmasının doğruluğuna inanmıştır. Dilin 'deyiş’teki arılığı düşünüş ile alakalıdır. Düşünüşün özü anlam ve anlamı bilmenin de yolu sözcükleri bilmektir.

Dil konusunda aşırı olduğunu pek çok kez dile getiren Ataç, bu tutumuyla kendi gibi düşünmeyen herkesle kavga halindedir. Eleştirilerindeki öfkeli dil, yerici üslup kimi zaman aşağılamalara değin varmıştır. Ona göre onun inancı mutlak doğrudur ve dile saygısı olan herkesin 'öyle’ yapması gerekir. Bu nedenle neredeyse her gün çıkan yazılarının bir köşesinde mutlaka bir dil eleştirisi bulunmuştur. Bu sert ve öfkeli tutumundan dostları da payını almıştır. Zaman zaman karamsarlığa düşse de ölümüne kadar bu inancını korumuştur. Ataç'ın dil davasında çelişkiler ve tutarsızlıklar bulunmaktadır: Arapça-Farsçaya karşı çıkışı karşısında Latince-Yunancaya inanışı, dilin köklerinin herkesçe bilinebileceği düşüncesi, varsayımlar ve ses benzerlikleri ile dil çözümlemeleri yapması, dili zenginleştirme düşüncesi ile birlikte yalın anlatımı savunması, konuşma dilini özleşmenin dayanağı olarak gördüğü halde kendi dilini konuşma dilinden uzak bir Türkçe haline getirmesi...

Doğal bir dil hiçbir bireyin tekelinde değişmez. Bireysel ve öznel müdahaleler sözcük düzeyi ile sınırlı kalmıştır. Keyfî olsun, bilimsel olsun bu müdahale sadece konuşurları isterse mümkün olabilir. Ataç'in dile müdahalesi sözcük düzeyinde kalmıştır. Deyiş ve düşünüş bahsindeki müdahaleleri ne kendi çağında ne de sonrasında yaygın bir fikre dönüşmemiştir. Dil, sözcük ve kurallardan oluşan bir yığın değildir. Yüzyıldan uzun bir süredir dil davası sözcük ve dil kuralları ile sürdürülmektedir. Dil, konuşucularının inisiyatifi ile gelişip şekillenmekte ve bütün kurallara rağmen 'yanlış'larını ısrarla yaşatabilmektedir. Dilin sadeleşme sürecinin başarılı olması, Arapça ile Farsçanın Türkçe üzerindeki hakimiyetinin özel bir çevreyle sınırlanması, halkın bu dili konuşma dili olarak benimsemeyişi ve milli bilincin ulus bilincini ve dolayısıyla dil bilincini de uyandırmasıyla Türkçe baskı altında tutulduğu bir yazı dili olmanın ötesine geçip nihayet konuşulan dil olarak hak ettiği değeri görmüştür. 


\section{Kaynaklar}

Ağakay, M. A. (1957). Ataç'ın dil görüşü. Türk Dili Dil ve Edebiyat Dergisi, VI (70), 557-558.

Aksoy, Ö. A. (1958). Dil üzerine: Bir düşünce, iki düzeltme (Dil dâvası - Ataç; Sana bana-bana bana; Hakîmsin-alîmsin). Türk Dili Dil ve Edebiyat Dergisi, VII (423), 418.

Aksoy, Ö. A. (1960). Dil üzerine: Bir düşünce, iki düzeltme (Ataç - aşırılık; tarafından; birbirlerine yan bakanlar). Türk Dili Dil ve Edebiyat Dergisi, IX (104), 418.

Ataç, N. (1951). Türkçesi: Kavuşma. Türk Dili Dil ve Edebiyat Dergisi, I (1), 23-25.

Ataç, N. (1959). Halk dili. Türk Dili Dil ve Edebiyat Dergisi, VIII (92), 444-446.

Ataç, N. (1961). Söyleşi: Dilimiz. Türk Dili Dil ve Edebiyat Dergisi, XI (129), 717-718.

Ataç, N. (1998a). Günce: 1. Can Yayınları.

Ataç, N. (1998b). Günce: 2. Can Yayınları.

Aydın, M. (2002). Nurullah Ataç'ta ana dili bakımı. Türk Dili Dil ve Edebiyat Dergisi, 2002/II (610), 841-851.

Aydın, M. (2004). Nurullah Ataç’ın Türkçenin söz varlığına katkısı. V. Uluslararası Türk Dil Kurultayı Bildirileri, 1, 343-349.

Balyemez, S. (2021). Nurullah Ataç'ın sözcüklerinin kaynakları. Selçuk Üniversitesi Edebiyat Fakültesi Dergisi, (45), 223-252.

Batu, S. (1965). Ataç ve Türk dili. Türk Dili Dil ve Edebiyat Dergisi, XIV (161), 368371.

Canpolat, M. (1967). Ataç nasıl yazardı?. Türk Dili Dil ve Edebiyat Dergisi, XVI (188), 589-594.

Çolpan, Y. (1968). Ataç’ın sözcükleri. Türk Dil Kurumu Yayınları.

Ergin, M. (2009). Türk dil bilgisi. Bayrak Basım/Yayım/Tanıtım.

Kartallığlu, Y. (2015). Carbognano'ya göre Osmanlı Türkçesi yazı ve konuşma dili ilkeleri. Dil Araştırmaları Dergisi, (16), 7-27.

Korkmaz, Z. (2003). Cumhuriyet döneminde Türk dilinde ve Türk dili alanında yaşanan gelişmeler. Türk Dili Dil ve Edebiyat Dergisi, LXXXVI (622),299-357.

Levend, A. S. (1960). Türk dilinde gelişme ve sadeleşme evreleri. Türk Dil Kurumu Yayınları. 
Maarif Vekaleti (1933). Birinci Türk dili kurultayı: Tezler, müzakere zabıtları. Devlet Matbaası.

Özdemir, E. (1968). Öz Türkçeci Ataç. Türk Dili Dil ve Edebiyat Dergisi, XVIII (200), 156-160.

Özdemir, E. (1977). Öz Türkçeci Ataç. Türk Dili Dil ve Edebiyat Dergisi, XXXV (308), 412-414.

Tekin, T. (1958). Ataç'ın dilciliği ve tilcikleri. Türk Dili Dil ve Edebiyat Dergisi, VII (80), 408-413.

Tekin, T. (1988). Atatürk ve Türk dilinde reform. Erdem Dergisi, (12), 1023-1044.

Tulum, M. (2011). Osmanlı Türkçesine giriş. Anadolu Üniversitesi.

Yücel, H. A. (1957). Hakkında çıkan yazılardan: Nurullah Ataç hakkında. Türk Dili Dil ve Edebiyat Dergisi, VI (70), 561-563. 